\title{
EVALUATION OF THE EXPECTED CLIMATIC CONDITIONS REGARDING CHERRY PRODUCTION IN CENTRAL HUNGARY
}

\author{
GAÁL, M. ${ }^{1}{ }^{*}-$ MÉZES, $Z^{2}{ }^{2}-$ SZABÓ, $Z^{2}{ }^{2}-$ SZENTELEKI, K. ${ }^{1}$ \\ ${ }^{1}$ Corvinus University of Budapest, Dept. of Mathematics and Informatics \\ 1118 Budapest, Villányi út 29-43., Hungary \\ (phone: +36-1-482-6261; fax: +36-1-466-9273) \\ ${ }^{2}$ University of Debrecen, Institute of Horticulture \\ 4032 Debrecen, Böszörményi út 138., Hungary \\ (phone: +36-52-508-477; fax: +36-52-526-934) \\ *Corresponding author \\ e-mail:marta.gaal@uni-corvinus.hu \\ (Received $5^{\text {th }}$ September 2011; accepted $7^{\text {th }}$ October 2011)
}

\begin{abstract}
Production possibilities and risks of a given plant are basically determined by climatic factors. Expected future climate is modelled by several climate scenarios. In this study results of the RegCM3 model downscaled to the Carpathian Basin were used. This paper focuses on the climatic conditions of cherry production in Central Hungary in three time periods: 1961-1990 as a base, 2021-2050 as the near future and 2071-2100 for the long-term analysis. Results show that in the near future fruit cracking risk could be higher, but in overall the expected changes are mostly favourable for cherry production. By the end of the century irrigation may be required for the secure and quality cherry production. It is also advised to re-evaluate the varieties according to the indicated changes, as a new orchard planted nowadays will have many productive years in the second period.
\end{abstract}

Keywords: climate change, cherry production, adaptation, fruit cracking, year types

\section{Introduction}

Security of agricultural production is very sensitive to weather and changing climate. However, it is very difficult to express the agriculture related effects of the climate change in numbers and figures, since the soil-plant-atmosphere system is very complex. The crop simulation models were created to give an approximate description of this complex system, and were applied also in Hungary in case of field crops (Fodor and Pásztor, 2010; Erdélyi, 2009).

Another method is the application of climatic indicators defined for certain phenological phases of a given plant (Diós et al., 2009; Ladányi et al., 2010a,b). This kind of examination can be done separately by seasonal effects, but an overall evaluation should be done, too. Also the climatic indicators can easily be related to risk values.

The other components of the climate change studies are the climate scenarios. Results from coarse resolution global climate models (GCM) can only be considered as a first-guess of regional climate change consequences of global warming (Bartholy et al, 2009). Regional studies for agricultural purposes have been possible since the global models were downscaled by statistical methods to high resolution $(10-20 \mathrm{~km})$ data. One technique that can be used to obtain climate change information at finer scales is the use of nested regional climate models (RCMs) (Torma et al, 2011). Expected regional climate change focused to the Carpathian Basin is modelled by four different RCMs, 
run by the Department of Meteorology, Eötvös Lóránd University (Bartholy et al, 2006; Torma et al., 2008) and by the Hungarian Meteorological Service (Szépszó and Horányi, 2008).

Studies on climate change impacts in agriculture are needed very much in order to find adaptation strategies. It is especially important in case of fruit production, where the change of varieties is slow and the orchards are planted for long time. This paper focuses on the expected climatic conditions and opportunities of cherry production in Central Hungary in the near future (2021-2050) and at the end of the century (20712100), compared to the base period of 1961-1990.

\section{Materials and methods}

\section{Climate data}

Climate data were provided by the Department of Meteorology of the Eötvös Lóránd University. The horizontal grid spacing is $10 \mathrm{~km}$ - the highest one reached by RegCM3 model - and the database contains daily data of precipitation and temperature for the baseline period (1961-1990) and for the future (2021-2050 and 2071-2100) using the A1B scenario.

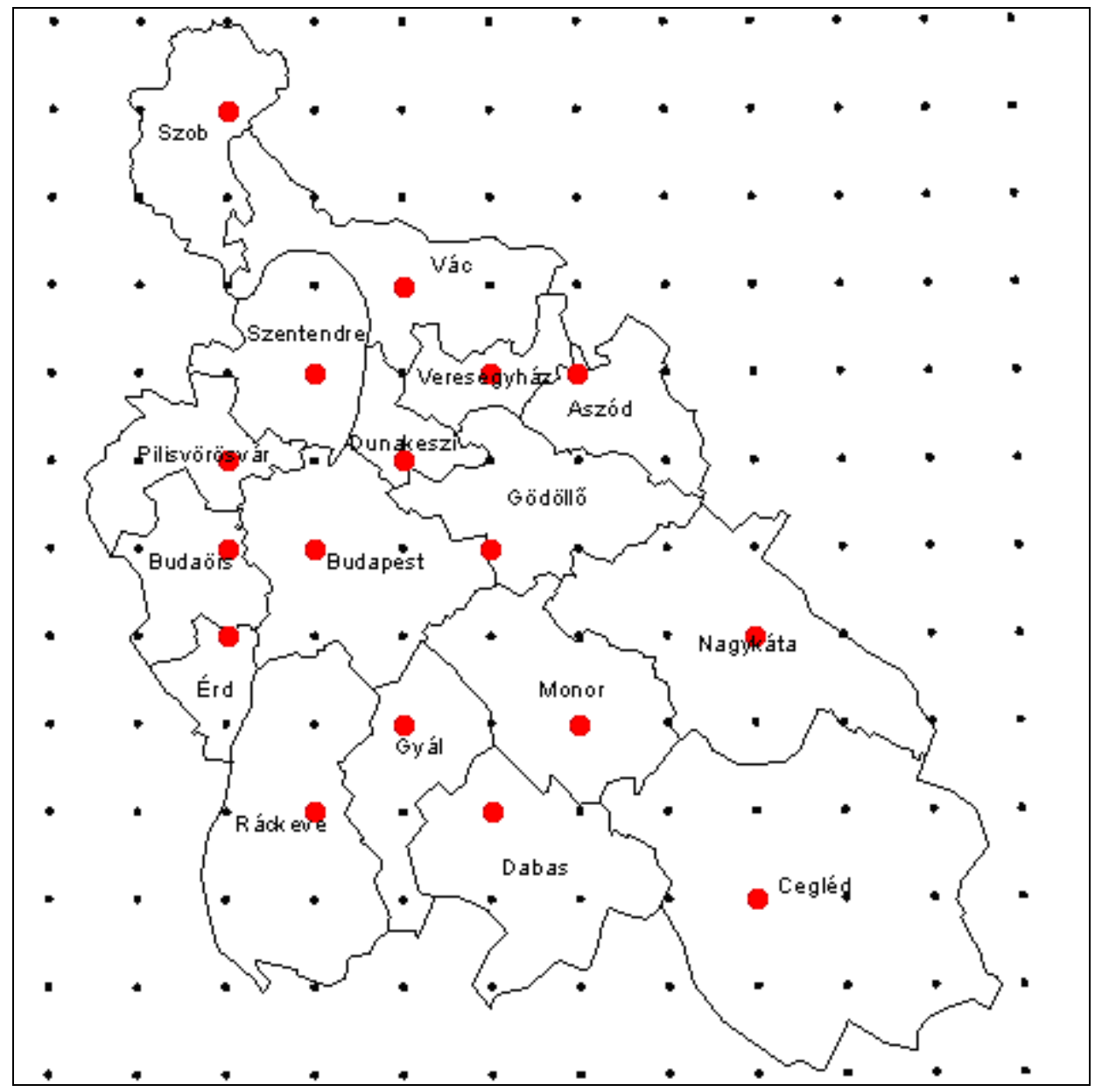

Figure 1. Local administrative units in Central Hungary and the grid of the meteorological data - data of red ones were analysed 
Data were converted into an Access database and software was developed to make the further calculations. The program can be parameterised according to the user's requirements. The necessary calculations for any year or time period such as decade, century, etc. can be calculated with this software.

Although the $10 \mathrm{~km}$ resolution grid covers the whole area of the Central Hungary region (Fig. 1), due to the huge amount of data, analyses were carried out characterising each of the 17 local administrative units (LAU 1) - subregions - by one grid point's data.

\section{Definition of climatic year types}

The evaluation of the important climatic factors of a certain plant in a specified phenophase can be done separately and estimated utility or risk values can be defined for them. Summarizing these values an overall utility or risk value can be calculated for each year. Having an adequate database, results can be extended both in time and space. However, these calculations do not take into account the interactions of the meteorological factors, so they can lead to false results.

Instead, in our work climatic year types were defined based on several factors. This method allows to concentrate the effects of climatic factors and to define some interactions among them. Utility values based on expert estimates were also added to the year types. In case of cherry production - like in case of growing possibilities of sour cherry (Szenteleki et al., 2011) - 12 climatic year types were defined, while the years not belonging in one of the categories, were defined as common or "normal" with a utility value of 0.88 . In the followings (Table 1-4) climatic year types are grouped according to the precipitation.

Table 1. Extreme dry climatic year types in case of cherry production

\begin{tabular}{c|c|c|c}
\hline Meteorological factors & $\begin{array}{c}\text { Extreme dry and } \\
\text { extreme cold }\end{array}$ & Extreme dry and cold & $\begin{array}{c}\text { Extreme dry and } \\
\text { warm }\end{array}$ \\
\hline Precipitation in April & $0-15 \mathrm{~mm}$ & $0-15 \mathrm{~mm}$ & $0-15 \mathrm{~mm}$ \\
Precipitation in May & $0-25 \mathrm{~mm}$ & $0-25 \mathrm{~mm}$ & $0-25 \mathrm{~mm}$ \\
Precipitation in June & $0-20 \mathrm{~mm}$ & $0-20 \mathrm{~mm}$ & $0-20 \mathrm{~mm}$ \\
Tmin January - February & below $-25^{\circ} \mathrm{C}$ exist & below $-17^{\circ} \mathrm{C}$ exist & not below $-17^{\circ} \mathrm{C}$ \\
Tmin March - April & below $-3^{\circ} \mathrm{C}$ exist & below $-1.5^{\circ} \mathrm{C}$ exist & not below $-1.5^{\circ} \mathrm{C}$ \\
Utility value (H) & 0.2 & 0.35 & 0.6 \\
\hline
\end{tabular}

Table 2. Dry climatic year types in case of cherry production

\begin{tabular}{c|c|c|c}
\hline Meteorological factors & $\begin{array}{c}\text { Dry and extreme } \\
\text { cold }\end{array}$ & Dry and cold & Dry and warm \\
\hline Precipitation in April & $15-25 \mathrm{~mm}$ & $15-25 \mathrm{~mm}$ & $15-25 \mathrm{~mm}$ \\
Precipitation in May & $25-50 \mathrm{~mm}$ & $25-50 \mathrm{~mm}$ & $25-50 \mathrm{~mm}$ \\
Precipitation in June & $20-40 \mathrm{~mm}$ & $20-40 \mathrm{~mm}$ & $20-40 \mathrm{~mm}$ \\
Tmin January - February & below $-25^{\circ} \mathrm{C}$ exist & below $-17^{\circ} \mathrm{C}$ exist & not below $-17^{\circ} \mathrm{C}$ \\
Tmin March - April & below $-3^{\circ} \mathrm{C}$ exist & below $-1.5^{\circ} \mathrm{C}$ exist & not below $-1.5^{\circ} \mathrm{C}$ \\
Utility value (H) & 0.2 & 0.75 & 0.86 \\
\hline
\end{tabular}


Table 3. Wet climatic year types in case of cherry production

\begin{tabular}{c|c|c|c}
\hline Meteorological factors & $\begin{array}{c}\text { Wet and extreme } \\
\text { cold }\end{array}$ & Wet and cold & Wet and warm \\
\hline Precipitation in April & $40-100 \mathrm{~mm}$ & $40-100 \mathrm{~mm}$ & $40-100 \mathrm{~mm}$ \\
Precipitation in May & $70-180 \mathrm{~mm}$ & $70-180 \mathrm{~mm}$ & $70-180 \mathrm{~mm}$ \\
Precipitation in June & $80-150 \mathrm{~mm}$ & $80-150 \mathrm{~mm}$ & $80-150 \mathrm{~mm}$ \\
Tmin January - February & below $-25^{\circ} \mathrm{C}$ exist & below $-17^{\circ} \mathrm{C}$ exist & not below $-17^{\circ} \mathrm{C}$ \\
Tmin March - April & below $-3^{\circ} \mathrm{C}$ exist & below $-1.5^{\circ} \mathrm{C}$ exist & not below $-1.5^{\circ} \mathrm{C}$ \\
Utility value (H) & 0.2 & 0.8 & 1 \\
\hline
\end{tabular}

Table 4. Extreme wet climatic year types in case of cherry production

\begin{tabular}{c|c|c|c}
\hline Meteorological factors & $\begin{array}{c}\text { Extreme wet and } \\
\text { extreme cold }\end{array}$ & Extreme wet and cold & $\begin{array}{c}\text { Extreme wet and } \\
\text { warm }\end{array}$ \\
\hline Precipitation in April & above $100 \mathrm{~mm}$ & above $100 \mathrm{~mm}$ & above $100 \mathrm{~mm}$ \\
Precipitation in May & above $400 \mathrm{~mm}$ & above $400 \mathrm{~mm}$ & above $400 \mathrm{~mm}$ \\
Precipitation in June & above $200 \mathrm{~mm}$ & above $200 \mathrm{~mm}$ & above $200 \mathrm{~mm}$ \\
Tmin January - February & below $-25^{\circ} \mathrm{C}$ exist & below $-17^{\circ} \mathrm{C}$ exist & not below $-17^{\circ} \mathrm{C}$ \\
Tmin March - April & below $-3^{\circ} \mathrm{C}$ exist & below $-1.5^{\circ} \mathrm{C}$ exist & not below $-1.5^{\circ} \mathrm{C}$ \\
Utility value (H) & 0.2 & 0.55 & 0.6 \\
\hline
\end{tabular}

\section{Risk of fruit cracking}

Cherry and sour cherry production has a specific risk factor. This is the fruit cracking due to the excessive precipitation in the harvest period, resulting decrease of quality and significant yield loss. In some extreme years the cracking damage can cause up to 80$100 \%$ loss in sweet cherry and about 40-50\% loss in sour cherry orchards (Christiensen, 1996, Csiszár, 2004).

According to an earlier study (Szenteleki et al., 2010) harvest period of sweet cherry is considered between $20^{\text {th }}$ May and $10^{\text {th }}$ July and four risk factors are calculated for every harvest day using the following algorithm:

- K2 risk factor: 10-6. days before harvest at least $15 \mathrm{~mm}$ rain occur once $\rightarrow$ $\mathrm{K} 2=0.15$; twice $\rightarrow 0.4$; three times $\rightarrow 0.7$

- K3 risk factor: 5-1. days before harvest at least $10 \mathrm{~mm}$ rain occur once $\rightarrow$ $\mathrm{K} 3=0.2$; twice $\rightarrow 0.5$; three times $\rightarrow 0.8$

- $\mathrm{K} 4$ risk factor: during harvest at least $5 \mathrm{~mm}$ rain occur once $\rightarrow \mathrm{K} 4=0.8$; twice $\rightarrow 1$

The overall risk factor is like follows:

- $\mathrm{K} 2+\mathrm{K} 3+\mathrm{K} 4=\mathrm{K} 5$; if $\mathrm{K} 5>1$, than $\mathrm{K} 5=1$.

To obtain the overall utility value of a given year, its utility value based on the climatic year types must be corrected with this risk value.

\section{Results}

\section{Overall evaluation of the Central Hungary region}

Central Hungary region is partitioned into 17 local administrative units (subregions), which have slightly different climatic and topographic characters. Despite that - for 
practical computing reasons - each of them was represented by one grid point's meteorological data. A joint evaluation of these data (17 places x 30 year for each period) allows giving a general estimation of the future climatic potential of cherry production.

Analysing the distribution of climatic year types regarding temperature (Fig. 2) the significant decrease of the extreme cold years can be observed. The number of cold years is increasing but there is no contradiction with the expected; it means that the formerly extreme cold years become only cold. Decrease of the number of normal years can be the reason of the continuous and significant increase of the warm years. Overall, a tendentious warming can be observed, which is favourable for quality cherry production. The utility value of the extreme cold years is very low because of the high risk of winter and spring frost damages. The significant decrease of the extreme cold years indicates the decrease of the frost damages, especially in long-term.

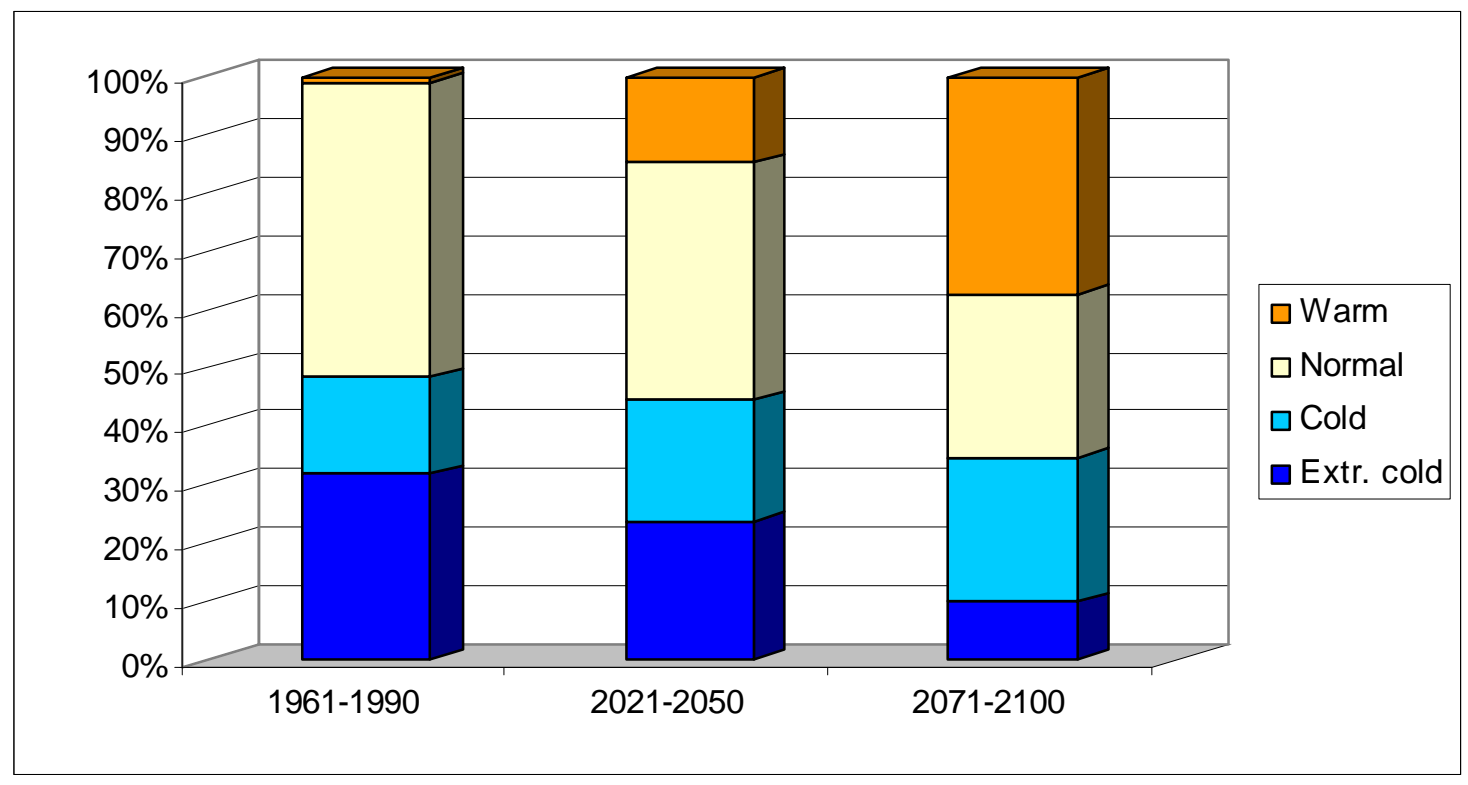

Figure 2. Distribution of climatic year types regarding temperature

However, results call the attention to a very important but rarely mentioned question: the re-evaluation of the varieties. The considerably extent of climate change would have a great impact on the time and length of ripening, dormancy and blooming period of cherry varieties (Ladányi et al., 2009). Milder winters can lead to the shortening of the deep dormancy period, resulting earlier blooming. As a consequence despite of the milder climate the risk of the spring frost can increase in case of some varieties, too. Changes in the well-known and so far successfully applied blooming time groups and pollination partners are also expected. Re-evaluation of the varieties according to the indicated changes is important in case of planning a new orchard. Counting with a 2025 year lifetime, orchards planted nowadays will have most of the productive years in the second period examined (2021-2050), already under changed climatic conditions.

In case of precipitation (Fig. 3) there are unfavourable tendencies, too. The number of extreme dry years is insignificant in the baseline period and also in the near future, but there is a significant increase by the end of the century (in every 5-6 years one extra dry year is expected). There is a continuous increase in the number of dry years and 
decrease in case of the normal years. Not completely though in a great part, these opposite tendencies correspond to each other. In case of the wet years a temporary increase, while in long-term their decrease can be observed. The number of extreme wet years is insignificant in all the three periods moreover this year type disappears.

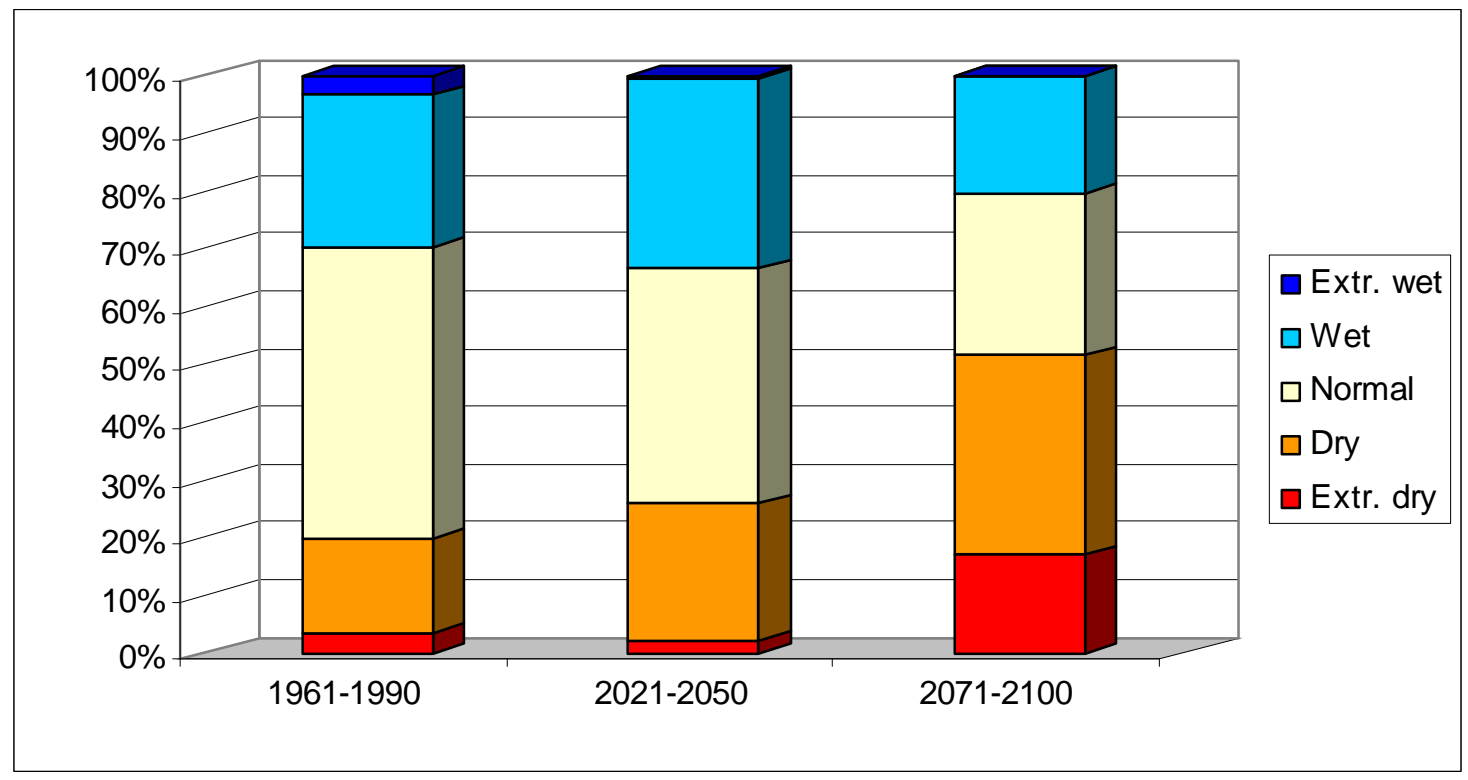

Figure 3. Distribution of climatic year types regarding precipitation

All together an aridification tendency can be observed, but the dry and warm $(\mathrm{H}=0.86)$ as well as the normal $(\mathrm{H}=0.88)$ year types are still favourable for cherry production. However, the significant number of extra dry years at the end of the century is a warning sign. In very dry years the fruit development is not appropriate and it affects the fruit size as well as the yield adversely. It calls the attention to the importance of irrigation. Changes are not so drastic that it would require immediate investments in existing orchards, but may be considered in the future.

Based on the climatic year types the continuous increase of the utility values can be observed (Table 5). However, in short-term the fruit cracking risk is higher, so the overall utility remains almost the same as it was in the baseline period. Two reasons can explain the increase of the fruit cracking risk in the near future. One of them is the increase of the number of wet years. At the same time, the number of dry years is also higher. If the cherries grow on drier conditions and precipitation is before harvest, cracking damage is higher than under balanced water conditions. Importance of irrigation possibility is great in this point of view and may be justified even in existing young plantations, while other protection methods are also available. In long-term, due to the more arid climate, the fruit cracking risk is decreasing again, and compared to the base period, $9 \%$ increase can be expected in the overall utility.

Table 5. Cherry production utility in Central Hungary

\begin{tabular}{c|c|c|c}
\hline Period & Climatic utility & Fruit cracking risk & Overall utility \\
\hline $1961-1990$ & $65 \%$ & $5 \%$ & $61 \%$ \\
$2021-2050$ & $70 \%$ & $11 \%$ & $62 \%$ \\
$2071-2100$ & $73 \%$ & $5 \%$ & $70 \%$ \\
\hline
\end{tabular}




\section{Spatial variability}

The overall evaluation of the Central Hungary region gives a general aspect but has the disadvantage of masking spatial variability. In the followings the spatial and temporal variability of the utility/risk values will be discussed.

As it can be seen in Table 6, in the near future the ranges of the utility values calculated from the 17 subregions - are similar to the ones of the base period, but at the end of the century the ranges are expected about the half these. This tendency can be observed in both climatic utility and risk of fruit cracking as well as in overall utility. Ranges of the overall utility values of the subregions are over $20 \%$ in the first two periods and about $10 \%$ in the future (standard deviations are approximately $6 \%$ and $3 \%$ ). It means that more favourable climatic conditions will appear in most of the subregions and the potential for cherry production will be more similar across the whole region.

Table 6. Ranges of the cherry production utility values in Central Hungary (17 subregions)

\begin{tabular}{c|c|c|c}
\hline Period & Climatic utility & Fruit cracking risk & Overall utility \\
\hline $1961-1990$ & $20 \%(51-70 \%)$ & $10 \%(3-12 \%)$ & $24 \%(44-68 \%)$ \\
$2021-2050$ & $17 \%(60-77 \%)$ & $11 \%(6-17 \%)$ & $22 \%(49-71 \%)$ \\
$2071-2100$ & $10 \%(68-78 \%)$ & $6 \%(3-8 \%)$ & $11 \%(63-74 \%)$ \\
\hline
\end{tabular}

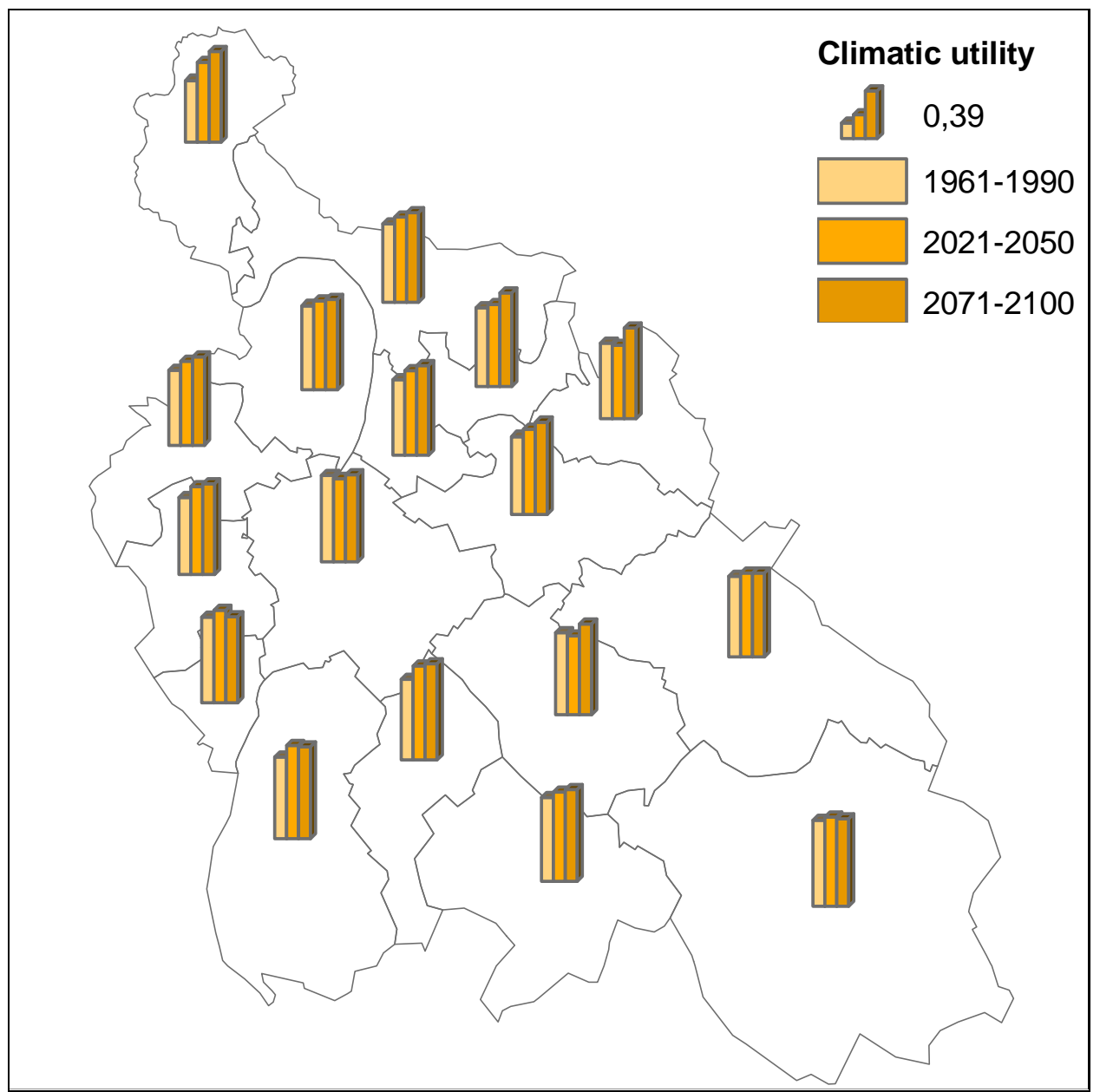

Figure 4. Climatic utility of the subregions regarding cherry production in Central Hungary (the value refers to the highest column in the chart symbol) 
As it was presented previously, the warming climate is favourable for cherry production. In the majority of the subregions a continuous increasing tendency of the climatic utility values can be observed (Fig. 4). This is especially characteristic in the northern part (Szob), where the utility value was the lowest in the base period. In some subregions (Budapest, Aszód, Monor) in the near future (2021-2050) the climatic utility value can slightly be lower (2-3\%) than in the base period. For the third period examined (2071-2100) the climatic utility values are always greater than in the base period.

According to the general results, the fruit cracking risk is always the highest in the period 2021-2050, except the surroundings of Ráckeve (Fig. 5). The increment is between 1-10\% compared to the base period, the greatest change is in Pilisvörösvár. However, the worst situation (highest risk) is expected in the subregions of Aszód, followed by Szob and Veresegyház.

As it was presented during the overall evaluation, at the end of the century the average of the cracking risk values is similar to the one of the base period. But the situation is more complex. There are some significant changes in the risk values - in Aszód it drops to the one-third, in Monor and in Szob to the half of the base value while in Cegléd, Dunakeszi and Szentendre the risk values are almost doubled.

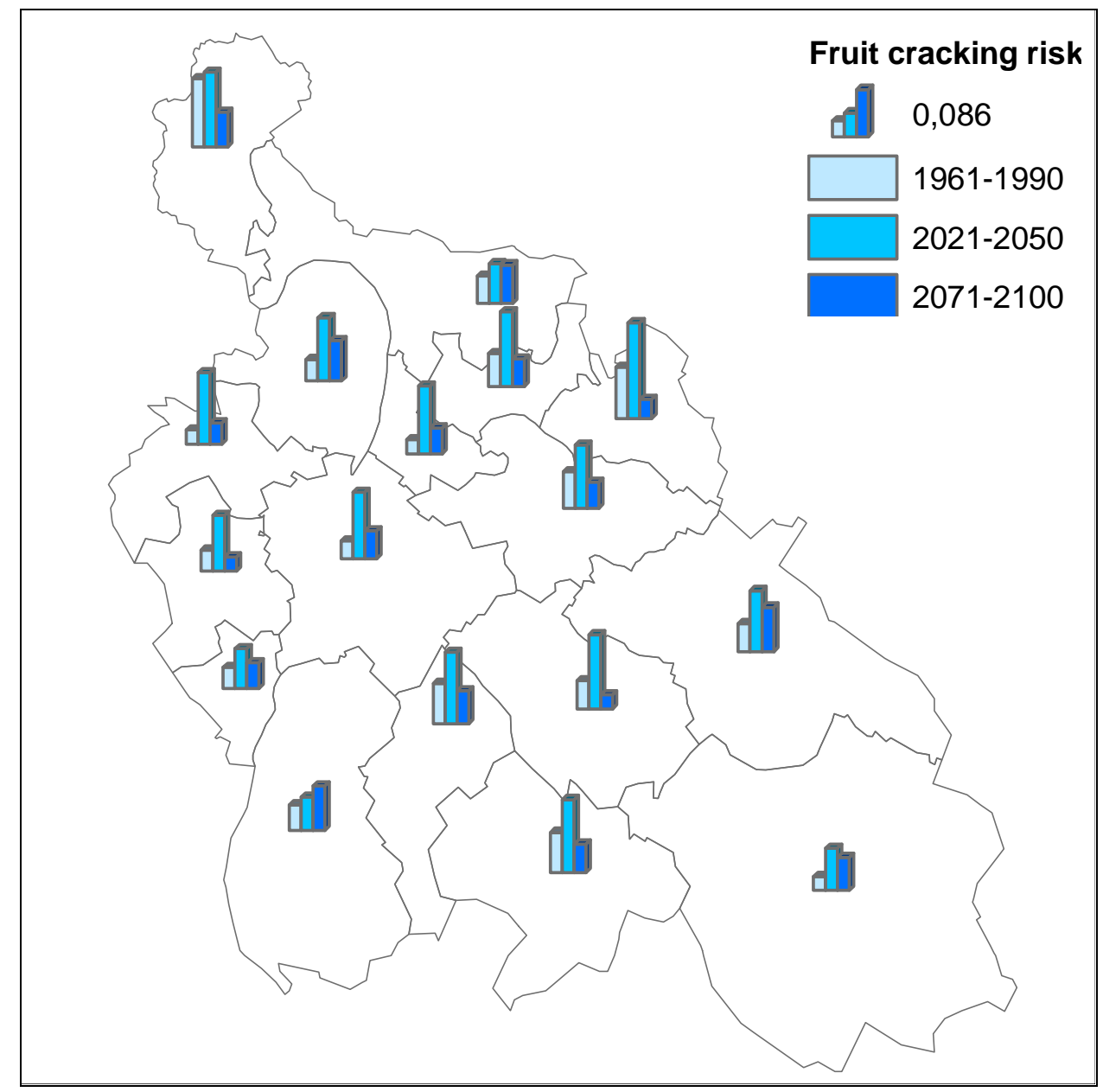

Figure 5. Fruit cracking risk of cherries in the subregions in Central Hungary (the value refers to the highest column in the chart symbol) 
In the near future (2021-2050) the fruit cracking risk is higher, so despite of the increasing climatic utility values, the overall utility remains almost the same as it was in the base period. There is an interesting pattern (Fig. 6), because on the western side of Central Hungary region mostly some increase, while on the eastern side some decrease can be observed. The most important changes are in Szob and Ráckeve (12\% and 8\% increase), where the increase of the cracking risk was quite small. By the end of the century the overall utility values are generally higher than they were in the base period. The exceptions are Budapest and Cegléd by $1 \%$ decrease and Érd with no change. By that time the overall utility value in Szob increases by $25 \%$, which is much more than in the other subregions. The subregion of Aszód shows also an outstanding result $(16 \%$ increase), as the cracking risk is very low in the third period.

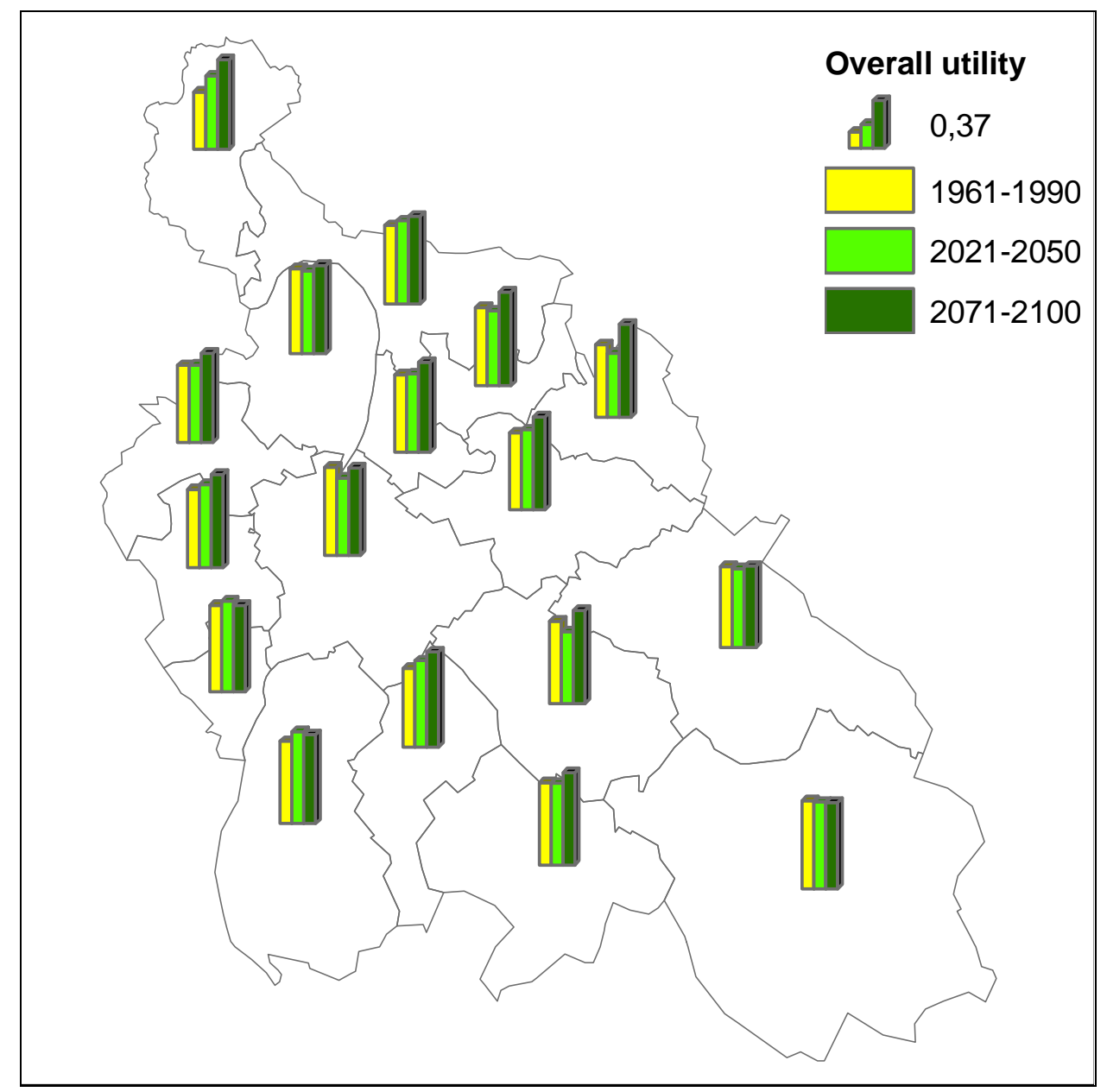

Figure 6. Overall utility of the subregions regarding cherry production in Central Hungary (the value refers to the highest column in the chart symbol)

Statistical data of cherry growing areas are usually structured by regions (NUTS 2 level) or counties (NUTS 3). Data by local area units (subregions) are available unfortunately only from the year 2001 (Table 7), when the most important areas were Cegléd, Ráckeve, Veresegyház, Budaörs and Érd. 
Table 7. Net cherry growing areas in the subregions (source: KSH, 2001)

\begin{tabular}{c|c}
\hline Local area (subregion) & Net cherry area (ha) \\
\hline Aszód & 0.16 \\
Budaörs & 28.89 \\
Budapest & 0.15 \\
Cegléd & 119.42 \\
Dabas & 0.15 \\
Dunakeszi & 0.00 \\
Érd & 25.17 \\
Gödöllő & 7.97 \\
Gyál & 0.00 \\
Monor & 4.50 \\
Nagykáta & 2.00 \\
Pilisvörösvár & 2.41 \\
Ráckeve & 65.11 \\
Szentendre & 9.64 \\
Szob & 0.00 \\
Vác & 4.71 \\
Veresegyház & 49.11 \\
\hline
\end{tabular}

Despite of the differences in time periods it is worth to compare these data with the overall utility values of the base period. It can be observed that most of the production was under appropriate climatic conditions, as Cegléd had the highest utility value $(0.68)$ in the base period. The same utility value has Budapest, but of course the growing area there is very low due to the high urbanisation. The overall utility value of Érd is also high (0.67) but the area of this subregion is small, and production of sour cherry is more important there. The other three areas have lower but still acceptable utility values: Ráckeve 0.64, Veresegyház 0.61 and Budaörs 0.6. (Some warming up between the base period and the survey date of the growing areas can also be considered.)

In the near future (2021-2050) both the climatic utility and the cracking risk are expected to increase in all of the subregions highlighted but with different extent. As a result, the overall utility value of Cegléd remains almost the same (0.67), the ones of Érd and Budaörs increase by 3-4\% and the value of Veresegyház decreases by $3 \%$. The most important change can be observed in Ráckeve by $7 \%$ increase.

Regarding the long-term tendencies the following overall utility values are expected: Cegléd and Érd 0.67 (the same as before), Ráckeve 0.69 (between the base and the near future), Budaörs and Veresegyház 0.72 (more than 10\% increase compared to the base period). The most significant changes can be observed in the areas (Szob, Aszód and Gyál), which were unsuitable for cherry production in the base period.

\section{Discussion}

Based on the presented results the following conclusions can be drawn concerning the future climatic conditions of cherry production:

- Decrease of the extreme cold and cold year types have a yield enhancing effect, first of all due to the decrease of the frost damages.

- Increase of the warm year types indicate the improvement in climatic conditions for quality cherry production. 
- The precipitation amount in the vegetative period shows a temporary slight increase in short-term, but in long-term its decrease can be observed. It calls the attention that appropriate infrastructure for irrigation may be required in the future.

- The uneven distribution of precipitation during the harvesting season in shortterm indicates increase of yield loss risk caused by fruit cracking, but in longterm this risk is moderate. Risk of fruit cracking might significantly reduced by adequate irrigation, so the above mentioned need for irrigation systems is important also from this point of view.

- The serious decrease of the extreme cold years and the increase of warm year types - despite the tendentious aridification - indicate an overall increase of utility values in cherry production and decrease of their variation.

The re-evaluation of the varieties according to the indicated changes is advised, as a new orchard planted nowadays will have most of the productive years in the second period examined (2021-2050). In this work international cooperation can help. With the method of spatial climatic analogy (Horváth et al., 2009) such regions can be found where the present climate is similar to the expected one of the studied area in the future. Thus, the future behaviour of the varieties can be evaluated and tested in the present days.

More solar radiation means warmer air temperature and higher temperature also in the upper layers of the soil. Therefore, not only in case of cultivars but in case of rootstocks it is advised choosing such kinds that tolerate summer heat having their roots in deeper soil layers. Irrigation is able to reduce soil temperature significantly and to avoid drought. When water supply of the soil is lower than the plant needs, it is ground draught. Drip irrigation, for example, is a good method to prevent ground draught. When the air temperature is above $30^{\circ} \mathrm{C}$, air humidity is usually very low, therefore fruit trees close stomas in the leaves and transpiration stops. Despite there is good water supply from the soil the plant shows draught symptoms. In this case drip irrigation is not effective at all, sprinkler irrigation is needed to cool down the surface of the leaves and raise air humidity in the orchard. This problem is not so important for sweet cherry but, for example, in case of apple production sprinkler irrigation during summer nights is a corner stone to reach the necessary coloration.

The rise of temperature can affect not only the growing but also the post-harvest technology. Even a small rise of temperature increases the risks during post-harvest handling. The transportability and shelf life of cherry fruits depend first of all on the time elapsed between picking and cooling as well as on the continuous temperature control of the supply chain. In addition, experiences show that fruits harvested on warmer days can be stored for shorter time as fruits harvested with the same technology but on cooler days.

To prevent fruit cracking in the second period (2021-2050) many protection methods can be applied (Simon, 2006). The most effective but very expensive protection technique is the plastic rain cover over the trees. Spraying with minerals (calcium) or metallic salts and fruit drying techniques need less investment. Risk of fruit cracking might significantly reduced by adequate irrigation, by means of maintaining balanced water conditions during vegetation period.

Up to now each of the 17 local administrative units - subregions - were represented by one grid point's data. As the $10 \mathrm{~km}$ resolution grid covers the whole area of Central Hungary region, analyses can be carried out for all grid points to obtain a more precise 
view. The only limitation factor of it is the computer capacity, as due to the large amount of data and the number of climatic parameters considered, at present the calculations take a rather long time.

Acknowledgements. The research was supported by the TÁMOP 4.2.1/B-09/1/KMR-2010-0005 and NFÜ TECH_08-A4/2-2008-0138 projects.

\section{REFERENCES}

[1] Bartholy, J., Pongrácz, R., Torma, Cs., Hunyady, A., (2006): Regional climate projections for the Carpathian Basin. - In: Láng, I. et al. (eds.) Proceedings of the International Conference on Climate Change: Impacts and Responses in Central and Eastern European Countries. Hungarian Academy of Sciences, Hungarian Ministry of Environment and Water, Regional Environment Center for Central and Eastern Europe, Budapest, 55-62.

[2] Bartholy J., Pongrácz R., Torma Cs., Pieczka I., Hunyady A. (2009): Regional climate model experiments for the Carpathian basin. - 89th AMS Annual Meeting / 21st Conference on Climate Variability and Change. http://ams.confex.com/ams/pdfpapers/147084.pdf. Phoenix, AZ. 5p.

[3] Christiensen, J.V. (1996): Rain-induced cracking of sweet cherries: it causes and preventation. - In: Webster, A.D., Looney, N.E. (eds.): Cherries: Crop physiology. Production and uses. CAB International, 297-327. pp.

[4] Csiszár, L. (2004): A cseresznye repedésének mechanizmusa és az azt befolyásoló egyes tényezők. - In: Inántsy F., Balázs K. (eds.): Integrált növénytermesztés. Meggy, cseresznye. Agroinform Kiadó, Budapest 200-205. pp.

[5] Diós, N., Szenteleki, K., Ferenczy, A., Petrányi, G., Hufnagel, L. (2009): A climate profile indicator based comparative analysis of climate change scenarios with regard to maize (Zea mays L.) cultures. - Applied Ecology and Environmental Research 7(3): 199214.

[6] Erdélyi, É. (2009): Sensitivity to climate change with respect to agriculture production in Hungary. - In: van Henten, E.J., Goense, D., Lokhorst, C. (eds): Precision Agriculture '09. Wageningen Academic Publisher, pp. 559-567.

[7] Fodor, N., Pásztor, L. (2010): The agro-ecological potential of Hungary and its prospective development due to climate change. - Applied Ecology and Environmental Research 8(3): 177-190.

[8] Horváth, L., Solymosi, N., Gaál, M. (2009): Use of the Spatial Analogy to Understand the Effects of Climate Change. - In: Mihailovic, D., Miloradov, MD. (eds): Environmental, Health and Humanity Issues in the Down Danubian Region, Multidisciplinary Approaches, World Scientific Publishing Co., New Yersey, London, Chapter 23, p. 215222.

[9] Ladányi, M., Persely, Sz., Szabó, T., Szabó, Z., Soltész, M., Nyéki, J. (2010): Climatic indicator analysis of blooming time for sour cherries. - International Journal of Horticultural Science 16 (1): 1-16.

[10] Ladányi, M. Persely, Sz., Szabó, T., Soltész, M., Nyéki, J., Szabó, Z. (2009): The application of a heat sum model for the budburst of sour cherry varieties grown at Újfehértó. - International Journal of Horticultural Science. 15(4):105-112.

[11] Ladányi, M., Persely, Sz., Nyéki, J., Szabó, T., Soltész, M., Szabó, Z. (2010): Climatic indicators regarding the rest period of sour cherry. - International Journal of Horticultural Science 16 (4): 49-52. 
[12] Simon, G. (2006): Review on rain induced fruit cracking of sweet cherries (Prunus avium L.), its causes and the possibilities of prevention. - International Journal of Horticultural Science 12 (3): 27-35.

[13] Szenteleki, K., Mézes Z., Nyéki J., Szabó Z., Gaál M., Soltész M. (2011): Meggy termékpályák meghatározó elemei. - „KLÍMA-21" Füzetek 64: 78-91.

[14] Szenteleki, K., Gaál M., Mézes Z., Soltész, M., Nyéki, J., Szabó, Z. (2010): Correlation of precipitation distribution and quality sweet cherry production. - International Journal of Horticultural Science 16(4): 39-43.

[15] Szépszó, G., Horányi, A. (2008): Transient simulation of the REMO regional climate model and its evaluation over Hungary. - Időjárás 112: 213-232.

[16] Torma Cs., Bartholy J., Pongrácz R., Barcza Z., Coppola E., Giorgi F., (2008): Adaptation and validation of the RegCM3 climate model for the Carpathian Basin. Időjárás 112(3-4): 233-247.

[17] Torma, Cs., Coppola, E., Giorgi, F., Bartholy J., Pongrácz R. (2011): Validation of a high resolution version of the regional climate model RegCM3 over the Carpathian Basin. Journal of Hydrometeorology 12: 84-100. 